\title{
ANTIANEMIA SUPPLEMENTATION COMBINATION WITH VITAMIN C ON HEMOGLOBIN LEVELS AMONG PREGNANT WOMEN IN PRIMARY HEALTH CARE CENTER, JEPARA, INDONESIA
}

\section{Poppy Diah Palupi ${ }^{1 *}$, Mohammed Safwan Ali Khan ${ }^{2,3}$, Kukilo Kenuk Karseno ${ }^{1}$}

\author{
${ }^{1}$ Department of Pharmacology and Clinical Pharmacy, Nusaputera School of Pharmaceutical \\ Science, Semarang, Indonesia \\ ${ }^{2}$ Department of Pharmacology, International School of Medicine (Hamidiye Uluslararasi Tip \\ Fakültesi), University of Health Sciences (Sağlic Bilimleri Üniversitesi), Mekteb-i-Tıbbiye-i- \\ Şahane Külliyesi, Selimiye Mah. Tibbiye Cad. No:38, 34668 Üsküdar, Istanbul, Turkey \\ ${ }^{3}$ Department of Biomedical Sciences, School of Medicine, Nazarbayev University, 5/1 Kerei- \\ Zhanibek Khandar Str.53 Kabanbay Batyr Avenue, Nur-Sultan city, 010000 Kazakhstan
}

Received October 23, 2020; Accepted February 10, 2021

\begin{abstract}
Blood volume escalation during pregnancy leads to an increase in iron needs. Pregnant women are prone to maternal anemia that is caused by iron, folic acid, vitamins $\mathrm{B}_{2}, \mathrm{~B}_{12}, \mathrm{~A}$, and $\mathrm{C}$ deficiency and may serve as causative factors that aggravate anemia. Concerning the problem, this clinical investigation determined the effect of antianemia supplementation and its combination with vitamin $\mathrm{C}$ on hemoglobin levels during pregnancy. This study is a quasi-experimental involving 34 patients who consumed antianemia supplements with or without vitamin $\mathrm{C}$. The treatment group was given a combination of antianemia supplement Fe Fumarate $180 \mathrm{mg}$-Folic Acid $400 \mathrm{mcg}$ and vitamin C $100 \mathrm{mg}$. The positive-control group was administrated with antianemia supplement Fe Fumarate 180 mg-Folic Acid 400 mcg. After 28 days, blood samples were taken to measure the hemoglobin levels. The hemoglobin levels were found to have a statistically significant difference $(p<0.05)$ between that group receiving a combination of antianemia-vitamin $\mathrm{C}$ and the other group administered with antianemia alone.
\end{abstract}

Keywords: Antianemia supplement; vitamin C; pregnancy; hemoglobin level

\section{INTRODUCTION}

The first trimester of gestation is a critical period for the fetus's development. During this period, the structure and organ systems of the fetus are developing. The incidence of miscarriages and congenital disabilities mainly occurs between 3 to 12 fetal weeks (Tsikouras et al., 2020). A high protein diet, oral iron, and folic acid supplementation are recommended for pregnant women to prevent maternal anemia, low birth weight, and preterm birth (Ghattas et al., 2003; Tunçalp et al., 2017). Iron deficiency is the most often encountered nutrient deficiency during pregnancy (Gernand et al., 2016). The leading causes are low oral iron and lack of iron in their diet (Crompton \&
Nesheim, 2002; WHO, 2017). Maternal anemia is caused by iron deficiency, while folic acid, deficiency of vitamins $\mathrm{B}_{2}, \mathrm{~B}_{12}, \mathrm{~A}$, and $\mathrm{C}$, and genetically inherited traits such as thalassemia might serve as superimposed causal factors (WHO, 2001). Anemia during pregnancy is identified when hemoglobin $(\mathrm{Hb})$ concentration is $<110 \mathrm{~g} / \mathrm{L}$ or $10.5 \mathrm{~g} / \mathrm{L}$ in the second trimester (Munasinghe, 2007; Stevens et al., 2013). The prevention of anemia can be done by consuming iron-rich foods, iron, and folate supplementation combined with vitamin C (Abbaspour et al., 2014; Abu-Ouf \& Jan, 2015). The diet of Indonesian women during pregnancy generally contains low iron food.

*Corresponding author: Poppy Diah Palupi

Email: poppydiahp@gmail.com 
The vegetable is known to have low iron quality or non-heme iron (Moustarah \& Mohiuddin, 2020; Skolmowska \& Głąbska, 2019) and requires ascorbic acid to stimulate absorption (Teucher et al., 2004). In terms of its bioavailability, non-heme iron is absorbed much less efficiently than heme iron, which is found in vegetables (Skolmowska \& Głąbska, 2019). Many studies showed that consuming food supplements such as vitamin $\mathrm{C}$ might increase the hemoglobin level during pregnancy (Nemo, 2020; Rimawati et al., 2018; Kadry et al., 2018; Triharini et al., 2019). Nevertheless, a study in Nigeria indicates no correlation between serum iron level and ascorbic acid consumption in the first and second trimester. In contrast, a positive correlation showed in the third trimester. Ascorbic acid plays a vital role in iron intestinal absorption, especially in low serum iron levels (Shu \& Ogbodoa, 2005). Iron deficiency anemia can be treated with oral iron supplements. The most commonly prescribed iron consumption is iron sulfate tablet three times daily with a lower dose option. Gastrointestinal disorder is a common side effect of a patient's adherence to iron therapy. Lower dose, iron consumption during meal times or enteric-coated options can avoid this side effect. Still, these strategies interfere with iron absorption and can lead to suboptimal clinical outcomes. Further investigations are needed to co-administrate vitamin $\mathrm{C}$ and iron therapy's optimal duration (Fei, 2015).

The benefits of vitamin $\mathrm{C}$ consumption to increase the $\mathrm{Hb}$ level during pregnancy still have to be investigated. Therefore, this study examined the effect of the combination of $\mathrm{Fe}$ supplementation plus vitamin $\mathrm{C}$ compared to the antianemia alone on pregnant women's $\mathrm{Hb}$ level.

\section{MATERIALS AND METHODS Study design}

The study was quasi-experimental using pre and post control design and conducted over four weeks period. Participants enrolled in this study were recruited from a community health center in Lebak village, Pakis Aji,
Jepara. The subjects were pregnant women in the first and second trimester who volunteered after signing the informed consent and received an antianemia supplement containing Fe Fumarate $180 \mathrm{mg}$-Folic Acid $400 \mathrm{mcg}$ manufactured by Phapros from Semarang, Indonesia. This study presented the physician prescription pattern of the antianemia supplement in the first and second pregnancy trimester in Pakis Aji primary health care center. Thirty-four participants were divided into two groups. Seventeen patients belonged to the positive-control group receiving antianemia supplement without vitamin C (with mean $\pm \mathrm{SD}$; age $26.41 \pm 3.28$ years), and the other 17 were placed in the treatment group receiving antianemia supplement combined with vitamin C $100 \quad \mathrm{mg}$ manufactured by Kimia Farma from Jakarta, Indonesia (with mean $\pm \mathrm{SD}$; age $28.18 \pm 4.22$ years). The supplements were given one tablet per day. Pregnant women with pre-eclampsia were excluded from this study. The $\mathrm{Hb}$ level was assayed by collecting the blood samples before administration and after four weeks of treatment using BC-2800 Mindray from China. The sample assessment was done at the Pakis Aji primary health care center laboratory.

\section{Ethical approval}

This study has received ethics approval from the Bioethics Committee of Medical Faculty, Sultan Agung Islamic University with the number of 310/V/2019/Komisi Bioetik, and was released on May 22 ${ }^{\text {nd }}, 2019$, before the initiation of the study.

\section{Control measurement}

The patients were requested to adhere to the dietary plan suggested by the physician. In addition, the physical condition, body weight, blood pressure, and $\mathrm{Hb}$ level were recorded, and the outcomes were informed to the patients.

\section{Laboratory examination}

Blood samples were collected before the administration of the antianemia supplement and after four weeks of treatment. The $\mathrm{Hb}$ levels were analyzed with the 
cyanmethemoglobin method (Norsiah, 2015) using Mindray from China. The blood was taken and put into tubes filled with $5 \mathrm{~mL}$ of Drabkin's reagent, incubated for 10 minutes, and analyzed with a spectrophotometer at 546 $\mathrm{nm}$ wavelengths. The Drabkin's solution's composition is potassium ferricyanide which binds heme (Ferro) to methemoglobin (Ferri), a cyanide ion that changes methemoglobin into cyanmethemoglobin. $\mathrm{KH}_{2} \mathrm{PO}_{4}$ was added into the solution to regulate the $\mathrm{pH}$ between 7.0 to 7.4 , and non-ionic detergent was also added to accelerate the lysis of erythrocytes that caused turbidity and interrupted the reading of the spectrophotometer (Gandasoebrata, 2007; McPherson \& Pincus, 2011).

\section{Statistical analysis}

Data analysis was carried out by univariate and bivariate. First, univariate analysis was performed to determine the socio-demographic frequency distribution of subjects. Simultaneously, the $\mathrm{Hb}$ levels bivariate were represented as mean \pm standard deviation (SD) and were analyzed using SPSS 17.0 software (SPSS Inc., Chicago, IL, USA). Second, the independent sample T-test was used to assess significant differences between control positive and treatment groups. Finally, a paired student T-test was applied to evaluate differences in group changes before and after the experiment.

\section{RESULTS AND DISCUSSION}

According to the univariate descriptive statistical analysis on the socio-demographic characteristic of the participants, most participants' ages (94\%) fell in a category within the range of 20 to 35 years $(27.29 \pm$ $3.83)$, and most of the pregnancy (47\%) was 20 to 23 weeks. Subject characteristics showed statistically insignificant differences $(p>0.05)$ between the control and treatment groups. The result of the descriptive analysis of participants' socio-demography can be seen in Table 1.

Table 1. Characteristics of subjects receiving an antianemia supplement

\begin{tabular}{|c|c|c|c|c|}
\hline Characteristics & $\begin{array}{c}\text { Total subjects } \\
\mathrm{N}(\%),(\text { Mean } \pm \text { SD })\end{array}$ & $\begin{array}{l}\text { Positive control group } \\
\mathrm{N}(\%),(\text { Mean } \pm \text { SD })\end{array}$ & $\begin{array}{c}\text { Treatment group } \\
\mathrm{N}(\%),(\text { Mean } \pm \text { SD })\end{array}$ & p-value \\
\hline Age (year) & $27.29 \pm 3.83$ & $26.41 \pm 3.28$ & $28.18 \pm 4.22$ & $0.183 *$ \\
\hline Pregnancy (week) & $21.56 \pm 3.21$ & $19.29 \pm 2.57$ & $23.82 \pm 1.94$ & $0.00^{*}$ \\
\hline $16-19$ & $8(23.5)$ & $2(11.8)$ & $6(35.3)$ & $2.00 * *$ \\
\hline $20-23$ & $16(47.1)$ & $6(35.2)$ & $10(58.7)$ & $1.00 * *$ \\
\hline $24-27$ & $10(29.4)$ & $9(53)$ & $1(6)$ & $6.40 * *$ \\
\hline Body weight (kg) & $64.72 \pm 2.94$ & $64.88 \pm 3.28$ & $64.41 \pm 3.20$ & $0.68 *$ \\
\hline \multicolumn{5}{|c|}{ Blood pressure (mmHg) } \\
\hline Systole & $128.27 \pm 14.17$ & $126.47 \pm 19.02$ & $133.53 \pm 13.20$ & $0.22 *$ \\
\hline Diastole & $83.85 \pm 5.45$ & $86.47 \pm 7.02$ & $82.35 \pm 4.37$ & $0.06 *$ \\
\hline
\end{tabular}

Pregnant women experience anemia if the iron absorption is obstructed. Gestation at less than 20 or more than 35 years old is more at risk of anemia because they need more iron for themselves and the fetus. Pregnancy under 25 years old is not optimal mentally and biologically, resulting in a lack of attention to iron fulfillment. Meanwhile, gestation over 35 years is more at risk of anemia because of declining reproductive organs (Rejeki \& Huda, 2014). The previous study shows that there is a significant relationship $(\mathrm{p}<0.05)$ between iron deficiency and pregnancy week, and the risk of anemia is increasing in the third trimester (Abiselvi et al., 2017; Nasyidah et al., 2013). As the pregnancy age gets higher, the demand for iron supply is also raised. The erythrocytes level in pregnant women reaches its peak at 20 to 25 weeks of gestational age, and most iron deposition in the fetus occurs after 30 weeks of pregnancy. The need for iron during pregnancy and breastfeeding is four times greater $(5.6 \mathrm{mg} /$ day) compared to nonpregnancy $(1.36 \mathrm{mg} /$ day) (Hallberg \& Hulthen, 2000). Many studies have been conducted to determine the relationship between gestational 
age and the risk of anemia, and the results were varied (De Camargo et al., 2013; Nair et al., 2016; WHO, 2001).

$\mathrm{The} \mathrm{Hb}$ level was analyzed before and after 28 days of administration of both antianemia tablets and in combination with vitamin $\mathrm{C}$. The data can be seen in Table 2 .

Table 2. Hb level in antianemia tablet alone group and antianemia-vitamin $\mathrm{C}$ group

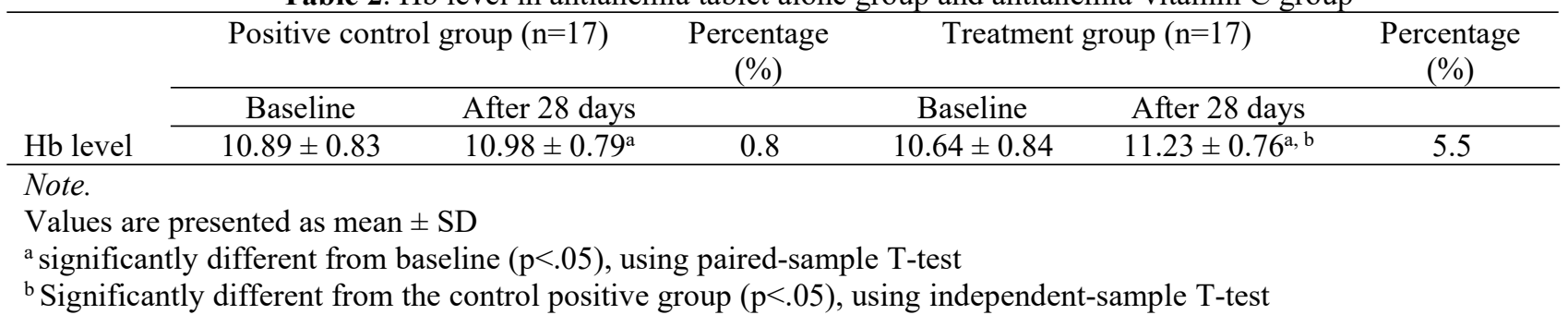

The $\mathrm{Hb}$ levels $(\mathrm{gr} \%)$ in the positivecontrol and treatment groups were found significantly increased $(\mathrm{p}<0.05)$, which each was raised by $0.8 \%$ and $5.5 \%$ after four weeks. The analysis of $\mathrm{Hb}$ level after vitamin $\mathrm{C}$ addition in antianemia supplement revealed a significant increase $(p<0.05)$ value after four weeks. In the initial examination of the $\mathrm{Hb}$ level, five pregnant women in the positivecontrol group and eight in the treatment group experienced mild anemia. A decrease in $\mathrm{Hb}$ levels was also seen in six of 14 subjects in the positive control group. Many factors causing this $\mathrm{Hb}$ reduction were identified, namely lack of compliance in taking antianemia tablets, lack of antenatal nutritional education, multiple pregnancies, and deficiency of dietary micronutrients intakes (Adam \& Ali, 2016; Ayensu et al., 2020), which resulted in disruption of iron absorption (Arisman, 2004).

In general, the $\mathrm{Hb}$ levels in Trimester II of pregnancy have decreased due to hemodilution. Blood dilution in pregnancy occurs by $30 \%$ to $40 \%$ of plasma volume increasing, $18 \%$ to $30 \%$ of red blood cells escalation, and $19 \%$ of $\mathrm{Hb}$ decreasing. The physiology of blood dilution is used to ease the burden on the heart. If the average $\mathrm{Hb}$ level is around $11 \mathrm{gr} \%$, then the result of hemodilution will be seen in anemia, and the $\mathrm{Hb}$ will be $9.5 \mathrm{gr} \%$ to $10 \mathrm{gr} \%$ (Wiknjosastro, 2002). Therefore, increasing $\mathrm{Hb}$ levels by consuming iron-rich foods or giving an antianemia supplement is necessary. During pregnancy and breastfeeding, the need for iron is four times greater than usual.
Vitamin C plays a potent enhancer to transform ferric ions into ferrous ions, so it is easily absorbed in higher $\mathrm{pH}$ levels in the duodenum and small intestine (Almatsier, 2009).

Iron absorption increases four times with vitamin $\mathrm{C}$ combination. In iron metabolism, vitamin $\mathrm{C}$ accelerates iron absorption in the intestine and its transfer to the blood. Vitamin $\mathrm{C}$ also plays a role in transferring iron from plasma to ferritin. Besides, vitamin $\mathrm{C}$ contains a component enriching biological reductants as an essential cofactor of reduction reactions of iron and copper in the function of oxygenation systems, carnitine biosynthesis, and an increase in absorption and metabolism of iron (Jacob \& Robert, 2005). Many studies were conducted to evaluate the effect of coadministration of vitamin $\mathrm{C}$ in various subjects. Research conducted on children over six years consuming orange juice rich in vitamin $\mathrm{C}$ and iron supplements indicates a twofold increase in iron absorption of ferrous fumarate (Balay et al., 2010). In a randomized controlled trial study on iron-deficiency anemia (IDA) patients, oral iron supplements alone are equivalent to oral iron supplements plus vitamin $\mathrm{C}$ to improve hemoglobin recovery and iron absorption (Li et al., 2020). A review comparing ascorbic acid (AA) and other organic acids shows that AA increases iron absorption more potently than other organic acids (Teucher et al., 2004). A recent investigation on iron-deficient women indicates that the absorption of oral iron, 
particularly when taken with meals, will be higher if given with ascorbic acid, about $6 \mathrm{mg}$ of ascorbic acid for each $1 \mathrm{mg}$ of iron (Stoffel et al., 2020). A combination of antianemia supplements with vitamin $\mathrm{C}$ is expected to increase the absorption of iron during pregnancy. The present study indicates that combining antianemia supplements with vitamin $\mathrm{C}$ enhances $\mathrm{Hb}$ levels compared to antianemia tablets alone in pregnant women's first and second trimesters. However, this study should be confirmed through further investigation due to the small number of patients enrolled. Therefore, prospective clinical research with a more significant number of patients is required to verify these findings.

\section{CONCLUSION}

Supplementation of vitamin $\mathrm{C}$ in antianemia tablets potentially increases the hemoglobin level compared to antianemia tablets alone in pregnant women's first and second trimester.

\section{REFERENCES}

Abbaspour, N., Hurrell, R., Kelishadi, R., 2014. Review on iron and its importance for human health. Journal of Research in Medical Sciences.

Abiselvi, A., Gopalakrishnan, S., Umadevi, R., Susilowati, Rizqi Fajri Ramadhani, Andi Sri Suriati Amal, F., 2017. Anemia among Pregnant Women in a Rural Area of Kancheepuram District, Tamil Nadu. International Journal of Community Medicine And Public Health, 4(7), 2400.

Abu-Ouf, N.M., Jan, M.M., 2015. The Impact of Maternal Iron Deficiency and Iron Deficiency Anemia on a Child's Health. Saudi Medical Journal, 36(2), 146-149.

Adam, I., Ali, A.A., 2016. Anemia During Pregnancy, in: Nutritional Deficiency. Intech Open, pp. 110-126.

Almatsier, 2009. Prinsip Dasar Ilmu Gizi. Gramedia Utama, Jakarta.

Arisman, 2004. Gizi Dalam Daur Kehidupan: Buku Ajar Ilmu Gizi. Penerbit Buku kedokteran EGC, Jakarta.
Ayensu, J., Annan, R., Lutterodt, H., Edusei, A., Peng, L.S., 2020. Prevalence of Anemia and Low Intake of Dietary Nutrients in Pregnant Women Living in Rural and Urban Areas in the Ashanti Region of Ghana. PLoS ONE, 15(1).

Balay, K.S., Hawthorne, K.M., Hicks, P.D., Griffin, I.J., Chen, Z., Westerman, M., Abrams, S.A., 2010. Orange but Not Apple Juice Enhances Ferrous Fumarate Absorption in Small Children. Journal of Pediatric Gastroenterology and Nutrition, 50(5), 545-550.

Crompton, D.W.T., Nesheim, M.C., 2002. Nutritional Impact of Intestinal Helminthiasis during the Human Life Cycle. Annual Review of Nutrition, 22(1), 35-59.

De Camargo, R.M.S., Pereira, R.A., Yokoo, E.M., Schirmer, J., 2013. Factors Associated with Iron Deficiency in Pregnant Women Seen at a Public Prenatal Care Service. Revista de Nutricao, 26(4), 455-464.

Fei, C., 2015. Iron Deficiency Anemia: A Guide to Oral Iron Supplements. Clinical Correlation, 7(2), 21-28.

Gandasoebrata, 2007. Penuntun Laboratorium Klinik. Dian Rakyat, Jakarta.

Gernand, A.D., Schulze, K.J., Stewart, C.P., West, K.P., Christian, P., 2016. Micronutrient Deficiencies in Pregnancy Worldwide: Health Effects and Prevention. Nature Reviews Endocrinology.

Ghattas, H., Fulford, T., Prentice, A., 2003. Effect of Moderate Anemia on Later Mortality in Rural African Children. Lancet, 361(9374), 2048-2050.

Hallberg, L., Hulthen, L., 2000. Prediction of Dietary Iron Absorption: An Algorithm for Calculating Absorption and Bioavailability of Dietary Iron | The American Journal of Clinical Nutrition | Oxford Academic. The American Journal of Clinical Nutrition, 71(5), $1147-1160$.

Jacob, J., Robert, A., 2005. Vitamin C, in: Modern Nutrition in Health and Disease. Waverly Company, Philadelphia. 
Li, N., Zhao, G., Wu, W., Zhang, M., Liu, W., Chen, Q., Wang, X., 2020. The Efficacy and Safety of Vitamin C for Iron Supplementation in Adult Patients With Iron Deficiency Anemia: A Randomized Clinical Trial. JAMA network open, 3(11), e2023644.

McPherson, Pincus, 2011. Henry's Clinical Diagnosis and Management Laboratory Methods, 22nd ed. Elsevier Saunders, Philadelphia.

Moustarah, F., Mohiuddin, S.S., 2020. Dietary Iron, in: Iron Metabolism. Springer US, 27-35.

Munasinghe, S., 2007. Anemia in Pregnancy in Malawi - A Review. Malawi Medical Journal, 18(4), 160.

Nair, M., Choudhury, M.K., Choudhury, S.S., Kakoty, S.D., Sarma, U.C., Webster, P., Knight, M., 2016. Association between Maternal Anemia and Pregnancy Outcomes: A Cohort Study in Assam, India. BMJ Global Health, 1(1).

Nasyidah, N., Wijayantie, H., Fitrianingrum, I., 2013. Hubungan Anemia dan Karakteristik Ibu Hamil Di Puskesmas Alianyang Pontianak, Jurnal Mahasiswa PSPD FK Universitas Tanjungpura.

Nemo, Maternal Health Group, 2020. Iron for Pregnant Women | MHNNS | Nutrition; Iron for Pregnant Women | MHNNS | Nutrition. Queensland.

Norsiah, W., 2015. Perbedaan Kadar Hemoglobin Metode Sianmethemoglobin Dengan dan tanpa Sentrifugasi Pada Sampel Leukositosis. Medical Laboratory Technology Journal, 1(2), 72-83.

Rejeki, S., Huda, A., 2014. Karakteristik ibu, konsumsi tablet fe dengan kejadian anemia pada kehamilan di wilayah kerja Puskesmas Kaliwungu Kabupaten Kendal, in: Prosiding Seminar Nasional \& Internasional. Universitas Muhammadiyah Semarang, Semarang, pp. 206-209.

Rimawati, E., Kusumawati, E., Gamelia, E., Sumarah, S., Nugraheni, S.A., 2018. Food Supplement Interventions For Increasing Hemoglobin Level on
Pregnant Women. Jurnal Ilmu Kesehatan Masyarakat, 9(3), 161-170.

Seifedine Kadry, Carla Sleem, Roudaina Abdel Samad, 2018. Hemoglobin Levels in Pregnant Women and Its Outcomes - MedCrave online. Biometrics \& Biostatistics International Journal, 7(4), 326-336.

Shu, E.N., Ogbodoa, S.O., 2005. Role of Ascorbic Acid in the Prevention. Biomedical Research, 16(1).

Skolmowska, D., Głąbska, D., 2019. Analysis of Heme and Non-heme Iron Intake and Iron Dietary Sources in Adolescent Menstruating Females in a National Polish Sample. Nutrients, 11(5).

Stevens, G.A., Finucane, M.M., De-Regil, L.M., Paciorek, C.J., Flaxman, S.R., Branca, F., Peña-Rosas, J.P., Bhutta, Z.A., Ezzati, M., 2013. Global, Regional, and National Trends in Hemoglobin Concentration and Prevalence of Total and Severe Anemia in Children and Pregnant and Nonpregnant Women for 1995-2011: A Systematic Analysis of Populationrepresentative Data. The Lancet Global Health, 1(1), e16.

Stoffel, N.U., von Siebenthal, H.K., Moretti, D., Zimmermann, M.B., 2020. Oral Iron Supplementation in Iron-deficient Women: How Much and How Often? Molecular Aspects of Medicine.

Teucher, B., Olivares, M., Cori, H., 2004. Enhancers of iron absorption: Ascorbic acid and other organic acids, in: International Journal for Vitamin and Nutrition Research. Int J Vitam Nutr Res, pp. 403-419.

Triharini, M., Nursalam, N., Sulistyono, A., Adriani, M., Hsieh, P.-L., 2019. Perceived Benefits and Intakes of Protein, Vitamin $\mathrm{C}$ and Iron in Preventing Anemia among Pregnant Women. Jurnal Ners, 13(2), 156.

Tsikouras, P., Deftereou, T., Anthoulaki, X., Bothou, A., Chalkidou, A., Gaitatzi, F., Tsirkas, I., Chalil Bourazan, A., Bampageorgaka, E., Stanulov, G., Chatzimichael, E., Michalopoulos, S., 
Petsidis, P., Iatrakis, G., Zervoudis, S., Lambropoulou, M., Rath, W., Galazios, G., 2020. Abortions in First Trimester Pregnancy, Management, Treatment, in: Induced Abortion and Spontaneous Early Pregnancy Loss - Focus on Management. Intech Open.

Tunçalp, Pena-Rosas, J.P., Lawrie, T., Bucagu, M., Oladapo, O.T., Portela, A., Metin Gülmezoglu, A., 2017. WHO recommendations on antenatal care for a positive pregnancy experience - going beyond survival. BJOG: An International Journal of Obstetrics and Gynaecology.

WHO, 2017. WHO I Nutritional anemias: tools for effective prevention and control NUTRITIONAL ANAEMIAS: TOOLS FOR EFFECTIVE PREVENTION AND CONTROL. Geneva, Switzerland.

WHO, 2001. Iron deficiency anemia. Assessment, prevention, and control. $A$ guide for programme managers, 47-62.

Wiknjosastro, 2002. Ilmu Kandungan. Yayasan Bina Pustaka Sarwono Prawirohardjo, Jakarta. 